\title{
A113 水素電力貯蔵システムの開発
}

\section{Development of Electricity Storage System}

$\begin{aligned} \text { O正 渡邊 } & \text { 久夫 (東芝) } \\ \text { 高橋 } & \text { 政彦 (東芝) } \\ \text { 吉野 } & \text { 正人 (東芝) }\end{aligned}$

\author{
正 吉村 良治（東芝） \\ 須山 章子（東芝） \\ 笠井 重夫（東芝原子カエンジ \\ ニアリングサービス)
}

\begin{abstract}
Hisao WATANABE and Ryoji YOSHIMURA, Toshiba Corporation ,8, shinsugita-Cho,Isogo-ku , Yokohama Masahiko TAKAHASHI and Shoko SUYAMA and Masato YOSHINO, Toshiba Corporation ,2-4,suehiro-Cho Tsurumi-ku, Yokohama

Shigeo KASAI, Toshiba Nuclear Engineering Services Corporation, ,8,shinsugita-Cho, Isogo-ku, Yokohama

Renewable energies have been introduced widely in Japan, so that necessity of electricity storage system has been increasing for load leveling and demand regulation. Hydrogen electricity storage system is suitable for large capacity and long time storage. This paper reports that hydrogen electricity system using SOEC (Solid Oxide Electrolysis Cell) and SOFC (Solid Oxide Fuel Cell) achieves high charge-discharge efficiency. And this paper shows the system diagram which contains sell-stack, high-temperature thermal storage, low-temperature thermal storage, and heat-exchangers. Furthermore this paper reports high temperature thermal storage test using $\mathrm{NaCl}$ as thermal storage material.
\end{abstract}

Key Words: Hydrogen, Solid Oxide Electrolysis Cell, Solid Oxide Fuel Cell, Thermal storage

\section{1. まえがき}

3.11 震災以降、太陽光、風力等の再生可能エネルギの 導入が国内で進められており、2012年度のエネルギ環境会 議にて、水力を除く再生可能エネルギの発電電力量を、2030 年には2010年に比べて8倍にする目標が決定された。太陽光、 風力の電力は、天候の影響を受けやすく変動が大きいので、 これらの総発電容量に占める割合が増えると、系統安定の ための電力貯蔵システムが必要になる。本報では、大容量・ 長時間蓄電に適した水素電力貯蔵システムと主要技術のひ とつである高温蓄熱について報告する。

\section{2. 水素電力貯蔵システム}

\section{2-1 システムの概要}

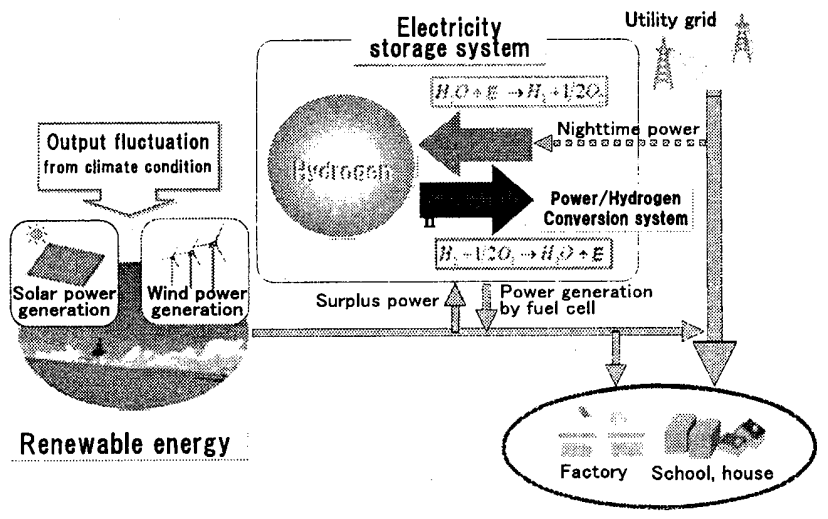

Fig.1 Renewable energy and hydrogen electricity storage system
水素電力貯蔵システムは、再生可能エネルギの出力が変 動して余剩電力が生じた場合に、この余剩電力により水電 解を行って水素を製造し、この水素を貯蔵して、必要な時 に燃料電池にて発電を行うものである。水素として貯蔵す るために、大容量・長時間蓄電に適している。

水素電力貯蔵システムの概念を図 2 に示す。本システム では、電解・電池方法は、効率の良い SOEC (Solid Oxide Electrolysis Cell ; 固体酸化物型電解セル) 、SOFC (Solid Oxide Fuel Cell; 固体酸化物型燃料電池) を採用している。 SOEC セルスタック部は、電解膜の性能を上げるため、約 $800^{\circ} \mathrm{C}$ の高温としている。このため、電池反応で生じた熱 を高温蓄熱装置で貯めて、電解反応時に再利用している。

更に、外部から与える空気、水等の昇温のために、再生 熱交換器、低温蓄熱を設けている。低温蓄熱は、高温蓄熱 と同様に、電池反応時に蓄熱し、電解反応時に放熱して、 水を蒸発させる。
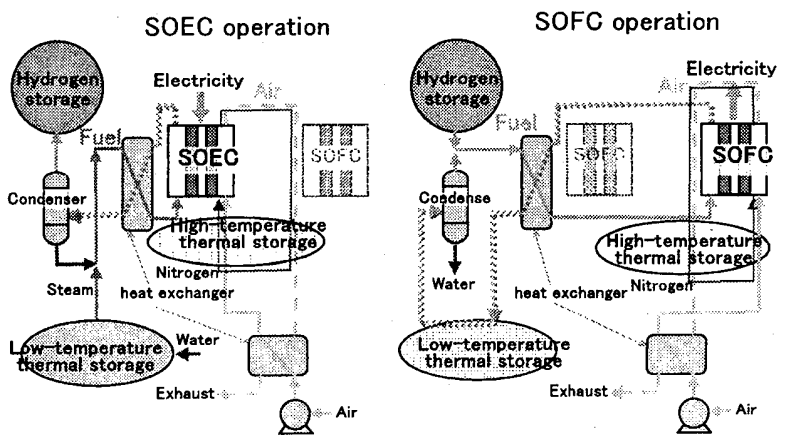

Fig.2 Hydrogen electricity storage system 


\section{2-2 性能評価}

（1）システムの原理

セルでの反応エネルギを(1)式に示す。各エネルギの温度 依存性を図 3 に示す。電解反応では、 $\Delta \mathrm{G}$ を電力で与える ので、高温では $\mathrm{T} \Delta \mathrm{S}$ が増大に伴い電解に必要な電力が低 減することが分かる。

$$
\begin{aligned}
& \Delta H=\Delta G+T \Delta S \\
& \Delta H_{E C}=\Delta H_{F C} \\
& \Delta H ; \text { 反応エネルギ }(J / \mathrm{kg}) \\
& \Delta G ; \text { ギブス自由エネルギ差 }(\mathrm{J} / \mathrm{kg}) \\
& T \text {; 温度 }(K) \\
& \Delta S ; \text { エントロピ差 }(J / \mathrm{kg} K)
\end{aligned}
$$

次に、システムの吸・発熱特性を図 4 に示す。発熱因子 は、（1)式における $\mathrm{T} \Delta \mathrm{S}$ と電気抵抗損失（ジュール熱）で ある。 $\mathrm{T} \Delta \mathrm{S}$ は、電池反応では発熱反忘であり、電解反忘で は吸熱反応となる。また、ジュール熱は発熱であり、電流 密度の 2 乗に比例する。電解反応では、電流密度に対して 吸熱 $(\mathrm{T} \Delta \mathrm{S})$ と発熱 (ジュール熱) が拮抗し電流密度を増 やすと発熱（ジュール熱）が吸熱（T $\Delta \mathrm{S}$ ）を上回るところ がある。この点を熱中立点という。この熱中立点より高電 流密度側では発熱、熱中立点より低電流密度側では吸熱と

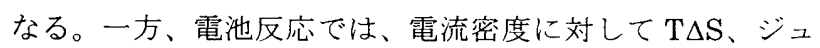
ール熱共にプラスのため、全電流密度に渡り発熱となる。 この電池反応での大きな発熱を、電解反応での吸熱領域で の運転時に流用することで高効率の充放電システムを構築 できる。

\section{（2）セル特性評価}

セルでの電流電圧特性を、(3)〜(7)式に、電流と水素流量 の関係を(8)式に示す。

$$
\begin{array}{ll}
E_{E C}=E o_{E C}+A S R_{E C} \times i & \cdots(3) \\
E o_{E C}=E t+\frac{R T}{2 F} \ln \left(\frac{P_{H 2} P_{O 2}{ }^{0.5}}{P_{H 2 O}}\right) & \cdots(4) \\
E_{F C}=E o_{F C}-A S R_{F C} \times i & \cdots(5) \\
E o_{F C}=E t+\frac{R T}{2 F} \ln \left(\frac{P_{H 2} P_{O 2}^{0.5}}{P_{H 2 O}}\right) & \cdots(6) \\
E t=\frac{\Delta G}{2 F} & \cdots(7) \\
Q=\frac{i}{2 F} & \cdots(8)
\end{array}
$$

$E ;$ 電圧 $(V), E o$; 開回路電圧 $(V), E t$; 理論電圧 $(V)$ $A S R$; 総括面抵抗 $\left(\Omega \mathrm{cm}^{2}\right), i$; 電流密度 $\left(A / \mathrm{cm}^{2}\right)$,

$Q$; 水素流量 $\left(\mathrm{mol} / \mathrm{s} \mathrm{cm}^{2}\right), \Delta G$; ギブス自由エネルギ $(\mathrm{J} / \mathrm{mol})$ $T ;$; 温度 $(K), P ;$ モル分率 $(-)$

添え字 $E C$; 電解、 $F C$; 電池、

$\mathrm{H}_{2}$ 水素、 $\mathrm{O}_{2}$;酸素、 $\mathrm{H} 2 \mathrm{O}$;水蒸気

（3)式より ASR（総括面積抵抗）が小さい程、電解電圧 $\left(E_{E C}\right)$ が下がり少ない電圧で水素を製造することができる。
また、(5)式より、ASR が小さい程、電池電圧（ $E_{F}$ が上 がり、大きな電力が得られる。従って、ASR が小さい程、 高い充放電効率が可能となる。また、ASR と同様に電流密 度(i)が小さい程、高い充放電効率が得られることが分かる。

東芝で製作したセルの ASR の一例を図 5 に示す。本図 は、ボタンセル単体を用いた試験から得られた I-V 特性よ り算出したものである。セルは、主に $\mathrm{Ni}$ サーメット（水 素極）/安定化ジルコニア（電解質）/ペロブスカイト型 複合酸化物（酸素極）で構成された水素極支持型セル $(\varphi 16 \mathrm{~mm}$ 、電極有効面積 : $\varphi 6 \mathrm{~mm})$ である。

また、(3)式の開回路電圧 $\left(E o_{E C}\right)$ は、(4)式に示すようにネ ルンストロスにより組成の影響を受ける。水素分率は低減 した方が開回路電圧 $\left(E o_{E C}\right)$ 低下する。そこで、水素循環 流量は低流量 (5\%) とした。また、水蒸気流量については、 過去の知見(1) を踏まえ燃料利用率 $85 \%$ とした。

図 5 に示す ASR の特性を用いて得られた水素原単価 $\left(\mathrm{kWh} / \mathrm{Nm}^{3}\right)$ と充放電効率を図 6 に示す。尚、電解反応 と電池反応での等電流密度における電圧比（ $\mathrm{E}_{\mathrm{FC}} / \mathrm{E}_{\mathrm{EC}}$; EVE (Electrochemical Voltage Efficiency) ) を充放電効 率とした。ASR が小さくなる高温で、また低電流密度で水 素原単価は小さくなり、充放電効率は向上し、 $800^{\circ} \mathrm{C}$ 以上、 $0.2 \mathrm{~A} / \mathrm{cm}^{2}$ 以下で $80 \%$ を超える効率となっている。

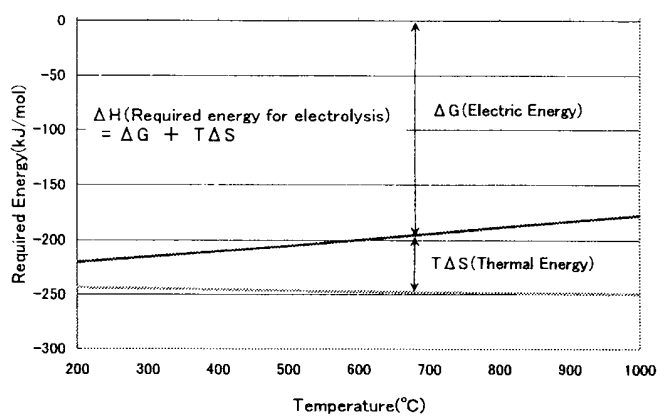

Fig.3 Temperature dependence of each energy

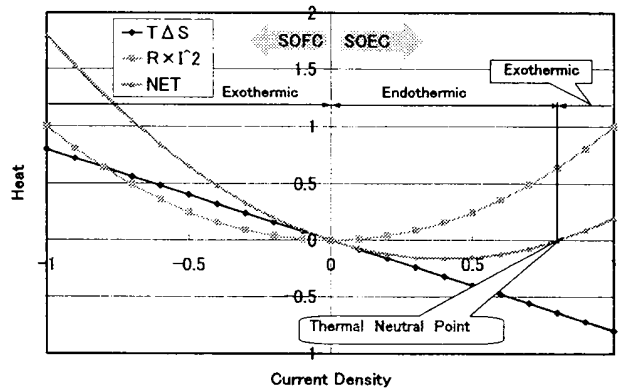

Fig.4 Endotherm-exotherm characteristics of system

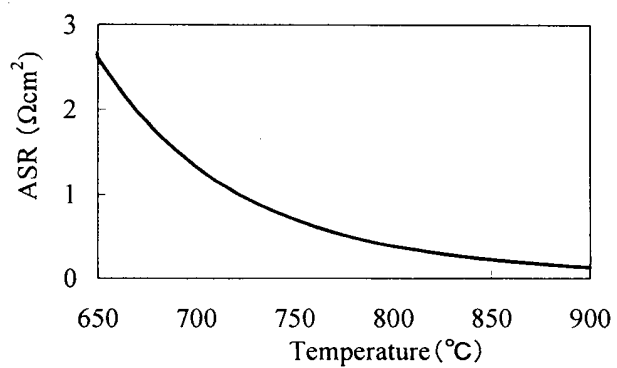

Fig.5 Example of ASR temperature 

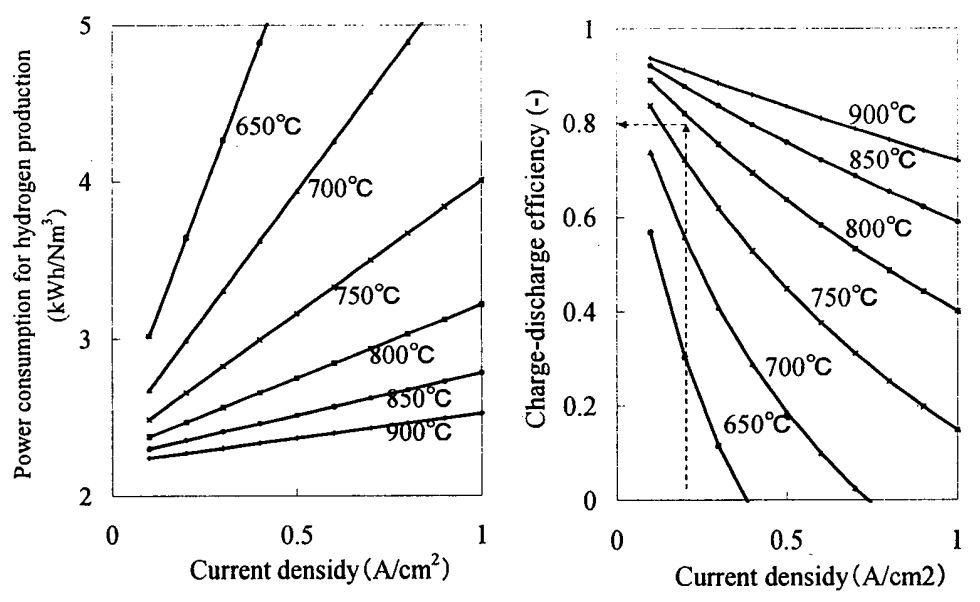

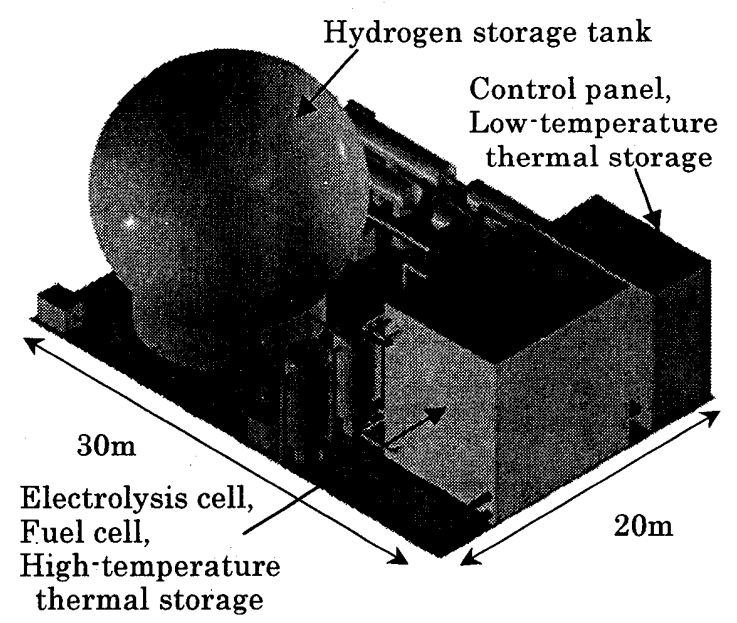

Fig. 8 Overall view of $5 \mathrm{MW}$ system ${ }^{(3)}$
(3) 系統構成

水素電力貯蔵システムの系統構成を図 7 に示す ${ }^{(3)}$ 。系統 は、空気、水素、水蒸気を循環させる主系統と、主系統と は独立した高温蓄熱とセルスタックを結ぶ高温蓄熱系統か ら成る。高温蓄熱系統は、セル運転温度の制御性の観点か ら、主系統とは別系統とし、冷媒は窒素ガスとしている。 電解運転において外部から流入する水は、再生熱交換器、 低温蓄熱で昇温しセルスタックに流入する。再生熱交換器 においては、水素と空気との熱交換は行わない構成とした。 また、生成した水素は水蒸気と水素の混合ガスであるため、 凝縮器で分離し、分離された水素の一部は、再循環させる。 また、セルスタック、高温蓄熱は、 $800^{\circ} \mathrm{C}$ 高温であるこ とから、一体化したセルユニットの中に設置される。電池 運転においても、運転温度を $800^{\circ} \mathrm{C}$ とするた、再生熱交 換器を設け、熱の回収を行っている。

$5 \mathrm{MW}$ (8 時間蓄電) システムのシステム概観を図 8 に示 す ${ }^{(3)}$ 。今後は、実プラント規模でのセル特性等の試験で得 られた知見の反映及び、システムの最適化を行い、設計の 詳細化を図っていく。
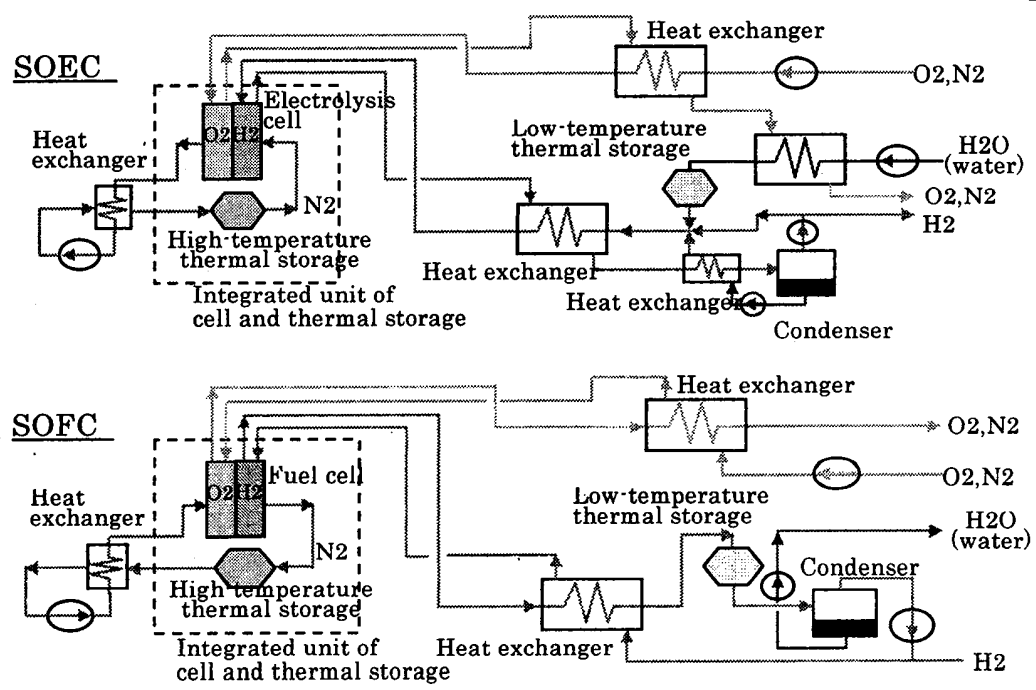

Fig.7 Plant system diagram ${ }^{(3)}$

\section{3. 高温蓄熱装置}

\section{3-1 高温蓄熱装置の構成}

蓄熱材は、運転温度 $800^{\circ} \mathrm{C}$ 近傍に融点があり、コストあ たりの蓄熱量が大きい $\mathrm{NaCl}$ を蓄熱材に選定している(2)。 この $\mathrm{NaCl}$ を耐食性に優れ、熱伝導率が大きい $\mathrm{SiC}$ のカプ セルの中に内封している。そして、その外側を窒素ガスが 流れている。

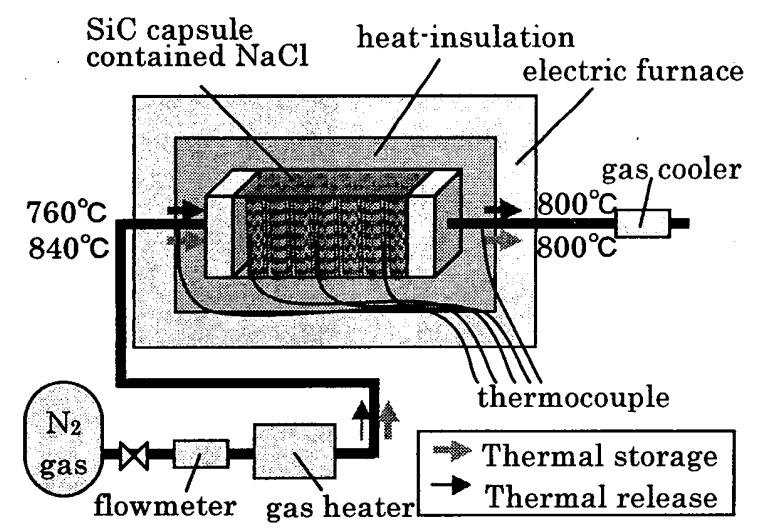

Fig.9 Configuration of model test

Table 1 Specification of model

\begin{tabular}{|c|c|}
\hline $\begin{array}{c}\text { Thermal storage } \\
\text { capacity }\end{array}$ & $720 \mathrm{~kJ} \quad$ (latent heat) \\
\hline $\begin{array}{c}\text { Mass flow of gas } \\
\text { Temperature } \\
\text { difference }\end{array}$ & $1 \sim 2 \mathrm{~g} / \mathrm{s}$ \\
\hline Capsule size & $40^{\circ} \mathrm{C}$ \\
\hline $\begin{array}{c}\text { Mass of thermal } \\
\text { storage material }\end{array}$ & $1.5 \mathrm{~kg}$ \\
\hline Number of capsules & $2 \times 7=14$ \\
\hline
\end{tabular}




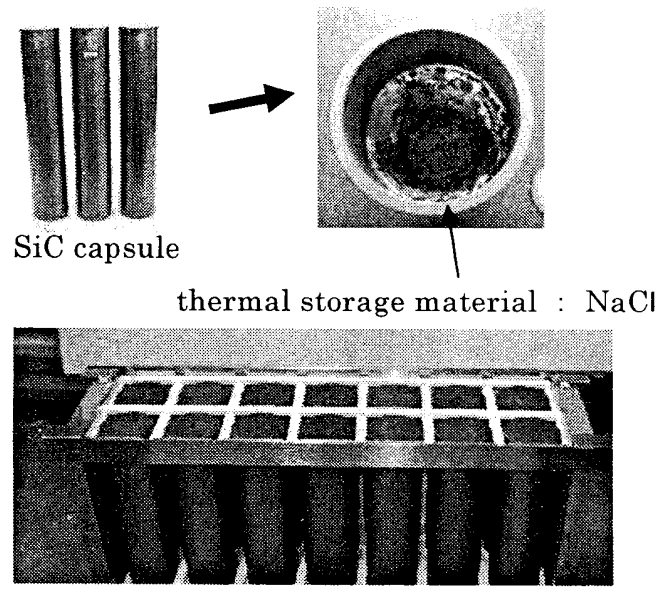

Fig.10 Assembled $\mathrm{SiC}$ capsules contained $\mathrm{NaCl}$

\section{3-2 縮小モデルでの蓄放熱要素試験}

蓄熱槽の縮小モデルの試験装置の構成を図 9 に、諎元を 表 1 に示す。蓄熱材である $\mathrm{NaCl}$ は $1.5 \mathrm{~kg}$ であり、この潜 熱は $720 \mathrm{~kJ}$ となる。 $\mathrm{NaCl}$ を内封した $\mathrm{SiC}$ カプセルは図 10 に示寸ように、ステンレスの枠組みに 2 列 $\times 7$ 本で配置し、 上下端のセラミックスベーサで $7 \mathrm{~mm}$ の隙間を開けて並べ た。流量は、伝熱量 $100 \mathrm{~W}$ を目安に、 $1 \sim 2 \mathrm{~g} / \mathrm{s}$ に設定した。

本試験では蓄熱材に着目した試験を行うため、外部への 放熱を低減するように試験体全体を電気炉の中に配置した。

計測は、蓄熱・放熱時の各部温度とガス流量を測定した。 温度は外径 $\phi 1 \mathrm{~mm}$ の TYPE K 熱電対を用いて測定した。

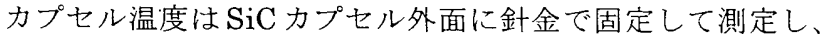
ガス温度はステンレス杂に針金を渡して、ここに温度計を 固定して測定した。温度計は事前に相対温度差を測定し、 この結果から平均温度に対寸る補正式を求め、相対温度差 が $0.25^{\circ} \mathrm{C}$ 以下になるようにしている。また、流量は質量流 量計を用いて測定した。

試験は高温のガスを流入させる蓄熱過程と、低温のガス を流入させる放熱過程の 2 種類を実施した。 $800{ }^{\circ} \mathrm{C}$ 前後で の蓄熱・放熱試験の結果を図 $11 、 12$ に示す。図 12 のカプ セル温度の時間変化を見ると、約 $800^{\circ} \mathrm{C}$ で潜熱に伴うと考 えられる折れ曲がりが見られる。

図 9 より約 3 時間にて、出ロガス温度が入ロガス温度程 度に上昇しており、蓄熱がほぼ終了している。ここでの、 理想蓄熱量に対する割合（蓄熱材利用率）を求めた。

$$
\eta_{\text {in }}=\frac{Q_{\text {in }}}{Q_{\text {im_in }}}
$$

$Q_{i n}:$ 蓄熱量 $\left(\right.$ オ、 $Q_{i m_{-} \_ \text {in }}$ : 理想蓄熱量(

蓄熱量はカプセルの蓄熱開始温度と終了温度（3 時間） から求めた。試験結果より求めた蓄熱量は、顕熱も考慮し $975 \mathrm{~kJ}$ となる。一方、理想蓄熱量はガス温度を $778^{\circ} \mathrm{C}$ と $851^{\circ} \mathrm{C}$ の間で変化させているので、1020kJ となる。蓄熱材 利用率 $\eta$ in $=96 \%$ となりほぼすべての蓄熱材を有効に利用

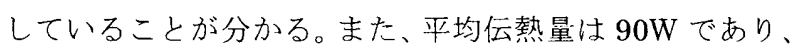
伝熱量目安 $100 \mathrm{~W}$ 程度の伝熱量が確認できた。

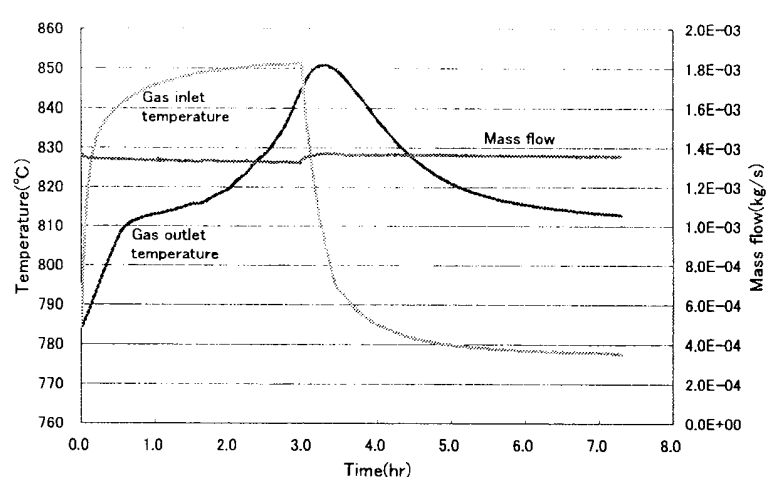

Fig.11 Test result - Gas inlet and outlet temperature and mass flow

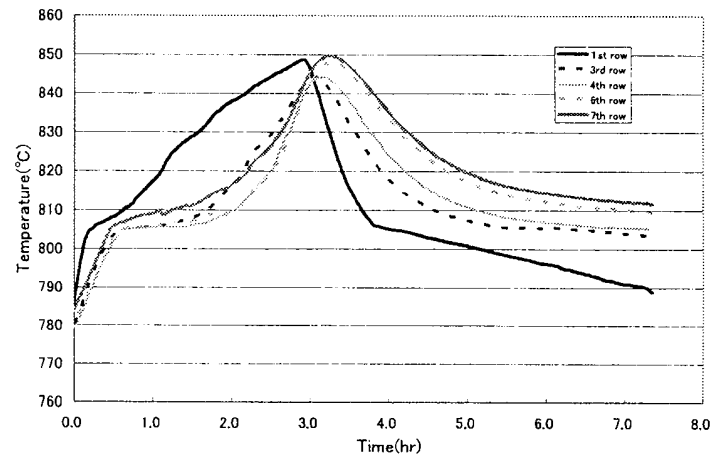

Fig.12 Test result - SiC capsule temperature

4. まとめ

再生可能エネルギの増大に伴い必要となる電力貯蔵シス テムのうち、大容量、長時間蓄電に適している水素電力貯 蔵システムの開発を行っており、以下の結果を得た。

1）七ル単体の特性については、高温、低電流密度で水素 原単価 $\left(\mathrm{kWh} / \mathrm{Nm}^{3}\right)$ は小さくなり、充放電効率は向上 する。ボタンセルサイズの試験より得られた ASR を用 いると、運転温度 $800^{\circ} \mathrm{C}$ 以上、電流密度 $0.2 \mathrm{~A} / \mathrm{cm}^{2}$ 以下 でセル性能は $80 \%$ を超える充放電効率となる。

2）電池運転で発生した熱を電解運転で利用するための高 温蓄熱装置、低温蓄熱装置及び、各運転時に外部から 供給される空気、水等をセル運転温度まで昇温する再 生熱交換器等を備えた水素電力賍蔵システムの系統構 成をまとめた。

3）高温蓄熱の性能評価については、蓄熱材に $\mathrm{NaCl}$ を用 いて約 $1000 \mathrm{~kJ} の$ 蓄熱・放熱試験（3 時間）を実施し た結果、蓄熱材利用率 $96 \%$ であり、ほぼすべての蓄熱 材を有効に利用していることを確認した。

\section{5. 参考文献}

（1）笠井、藤原、山田他、高温水蒸気電解に上る原子力水 素製造の研究、日本原子力学会和文論文誌、 Vol8,No.2,p122·141(2009)

（2）須山、笠井、高橋他、水素電力貯蔵システム用高温蓄 熱セルの開発、日本セラミックス協会第 25 回秋季シンポ ジウム講演予稿集、1A06(2012)

(3) NEDO 委託研究平成 24 年度成果報告書、再生可能工 ネルギーの水素電力貯蔵・允放電システムに関する検討 